\title{
Bark Characteristics of Scots Pine Logs ${ }^{\dagger}$
}

\author{
Ferréol Berendt ${ }^{1, *}$, Erik Pegel ${ }^{1}$, Lubomir Blasko ${ }^{2,3}$ and Tobias Cremer ${ }^{1}$ \\ 1 Department of Forest Utilization and Timber Markets, Eberswalde University for Sustainable Development, \\ 16225 Eberswalde, Germany; erik.pegel@hnee.de (E.P.); tobias.cremer@hnee.de (T.C.) \\ 2 Landeswaldoberförsterei Chorin, Landesbetrieb Forst Brandenburg, 16225 Eberswalde, Germany; \\ Lubomir.Blasko@lfb.brandenburg.de \\ 3 Department of Forest Harvesting, Logistics and Amelioration, Technical University Zvolen, \\ 96001 Zvolen, Slovakia \\ * Correspondence: ferreol.berendt@hnee.de \\ + Presented at the 1st International Electronic Conference on Forests - Forests for a Better Future: Sustainabil- \\ ity, Innovation, Interdisciplinarity, 15-30 November 2020; Available online: https://iecf2020.sciforum.net.
}

Citation: Berendt, F.; Pegel, E.;

Blasko, L.; Cremer, T. Bark

Characteristics of Scots Pine Logs.

Environ. Sci. Proc. 2021, 3, 66

https://doi.org/10.3390/IECF2020-

08020

Academic Editors: Angela Lo Monaco, Cate Macinnis-Ng and Om P. Rajora

Published: 12 November 2020

Publisher's Note: MDPI stays neutral with regard to jurisdictional claims in published maps and institutional affiliations.

Copyright: $\left(C^{2} 2020\right.$ by the authors. Licensee MDPI, Basel, Switzerland. This article is an open access article distributed under the terms and conditions of the Creative Commons Attribution (CC BY) license (http://creativecommons.org/licenses/by/4.0/).

\begin{abstract}
The wood of Scots pine (Pinus sylvestris L.) shows good properties as building and construction timber but also as furniture or pulp and paper, and thus, is one of the most commercially important European tree species. Scots pine are mostly harvested and processed with a high degree of mechanization. In Northeast Germany (federal states of Brandenburg and Berlin), 36\% of harvested Scots pine have a diameter at breast height $(\mathrm{DBH})$ between 7 and $19.9 \mathrm{~cm}$. As a typical industrial wood assortment, a large proportion of the resulting small-sized logs are used in the wood industry to produce boards. Although bark is considered a by-product or waste product of the industry, no actual study has quantified the bark thickness, bark volume, bark mass and bark damage of such Scots pine logs. Therefore, the bark characteristics from 50 logs from 10 different piles were analyzed. Bark volume was quantified using the water displacement method, bark mass by weighing, bark thickness with a precision caliper and bark damage by tape measurements. The diameters of the analyzed $150 \log$ discs were normally distributed and the mean value was $12.9 \mathrm{~cm}$. The results showed average bark damages from $12.0 \%$, which were mostly caused during the felling and processing of logs with the harvester. No significant correlation was found between double bark thickness (mean: $3.0 \mathrm{~mm}$ ) and the diameter; whereas fresh bark volume (mean: $5.6 \%$ ) and dry bark mass (mean: 3.3\%) were significantly affected by the diameter. As shown for spruce by other authors, bark characteristics may change over time and therefore, should be measured regularly. Moreover, it was shown that bark parameters are site dependent. Thus, quantifying bark characteristics for economically important tree species at both the local and national scale is of great relevance. More detailed analyzes are described by Berendt et al. (2021) [1].
\end{abstract}

Keywords: bark thickness; bark volume; bark damage; industrial wood

Supplementary Materials: The following are available online at https:/www.mdpi.com/article/10.3390/IECF2020-08020/s1.

Data Availability Statement: The datasets analyzed during this study are available from the corresponding author on reasonable request.

\section{References}

1. Berendt, F.; Pegel, E.; Blasko, L.; Cremer, T. Bark proportion of Scots pine industrial wood. Eur. J. Wood Wood Prod. (Holz als Roh- und Werkstoff) 2021, 128, 268, doi:10.1007/s00107-021-01657-7. 